BIOMEDICAL AND BIOSOCIAL ANTHROPOLOGY
$\begin{gathered}\text { Official Journal of the International Academy } \\ \text { of Integrative Anthropology } \\ \text { journal homepage: http://bba-journal.com }\end{gathered}$

\title{
The prospects of finding new treatments for acne
}

\section{Kryzhanovska A. V., Sidko I. Y., Shkarupa V. M., Dudar A. O., Gorbatyuk S. M.}

National Pirogov Memorial Medical University, Vinnytsya, Ukraine

ARTICLE INFO

Received: 09 October 2020

Accepted: 10 November 2020

UDC: $616.53-002.25-$

08:577.18:632.953.1

CORRESPONDING AUTHOR

e-mail: 2205avk1965@gmail.com Kryzhanovska A. V.
An important role in the development of acne is played by the activity of the skin microflora (namely the bacteria Propionibacterum acnes) and members of the genus Staphylococcus. In the schemes of complex treatment of patients with this disease, antibiotics from among macrolides or lincosamides are mainly used. It is of interest to study the current state of susceptibility of staphylococci and propionic bacteria to these drugs, as well as to other antimicrobial agents in order to determine the prospects for expanding the arsenal of methods for treating acne. The aim of the study was to study the susceptibility of microorganisms involved in the development of acne to antimicrobials and antagonistic effects of probiotic strains of lactobacilli. We conducted a bacteriological study of the content of rash elements in 60 patients with acne. The biological characteristics of 40 strains of Staphylococcus spp. and 15 strains of Propionibacterum acnes isolated and researched. The sensitivity of microorganisms to antibiotics and antiseptics was determined by the disco-diffusion method and the method of serial double dilutions of drugs in a liquid nutrient medium. Determination of the sensitivity of acne pathogens to the antagonistic effect of lactobacilli was performed by the method of two-layer agar by reducing the number of microorganisms. The results of the study made it possible to establish that the isolated strains of bacteria show a low level of sensitivity to antimicrobials, which in medical practice are most often used for topical therapy of acne. Only $17.5 \%$ of isolated staphylococcal strains were sensitive to erythromycin, only $45.0 \%$ of strains of this species were sensitive to clindamycin. Strains of Propionibacterum acnes showed a higher level of sensitivity to antibiotics than staphylococci. However, the established indicators do not allow to consider highly effective means for treatment of acne on their basis. At the same time, a high level of sensitivity of acne pathogens to antiseptic drugs decamethoxine and Aeroplysinin 1 and antagonistic effect of Lactobacillus acidophilus was established. Thus, the strains of Propionibacterum acnes and Staphylococcus spp., involved in the development of acne, are characterized by high levels of resistance to erythromycin, clindamycin, chloramphenicol, benzoyl peroxide, which are now the basis of the arsenal of topical therapy for patients with this disease. There is a need to find new effective drugs for the etiotropic therapy of acne.

Keywords: skin microflora, acne, antibiotics, antiseptics.

\section{Introduction}

In the context of the global spread of the phenomenon of polyresistance of microorganisms to antimicrobials, the urgency of finding treatments for diseases of microbial etiology is constantly growing. Despite the development of the latest medical technologies, the number of skin diseases of microbial origin is growing. One of the most common dermatoses that significantly impairs the quality of life of patients is acne. Acne (acne vulgaris, acne) affects more than $85 \%$ of people aged 12 to 24 years, $8 \%$ of people aged 25 to 34 years and $3 \%$ of people aged 35 to 44 years. In $5-15 \%$ of patients the disease has severe forms, which result in significant cosmetic defects in the form of hypo- and hypertrophic scars. Since acne is most often localized on exposed areas of the skin (face and upper torso), patients develop psycho-emotional disorders due to low self-esteem and peculiarities of perception in the social environment $[3,11,21]$.

The pathogenesis of acne is complex and multifactorial, involving a number of exogenous and endogenous factors. The main pathogenetic factors that play an important role in the development of acne are follicular hyperkeratosis, microbial colonization of Propionibacterium acnes, sebum 
hyperproduction and complex inflammatory mechanisms, including both innate and acquired immunity. It is believed that the starting point in the development of the disease is androgen-dependent hyperproduction of sebum with simultaneous acceleration of keratinization of the follicular epithelium, which create favorable conditions for the activation of autochthonous microflora. Propionibacterium acnes inhabit deep parts of follicles and closed comedones, hydrolyze sebum and block its protective function. Polymorphonuclear leukocytes, which absorb Propionibacterium acnes, release hydrolytic enzymes that destroy the epithelium, cause inflammatory processes, which destroy the structure of the dermis, and activate the complement system. Under these conditions, epidermal staphylococci, the products of which are a trigger of neutrophilic inflammation and the formation of pustules, are able to realize their pathogenic potential [2, 9, 16, 19]. The colonization density of Propionibacterium acnes skin changes with age, reaching a maximum in adolescence. The largest number of these bacteria is in seborrheic areas, as sebum is a nutrient medium for them. Propionibacterium acnes directly and indirectly involved in the occurrence of non-inflammatory (open, closed comedones) and inflammatory (papules, pustules, nodules) elements of the lesion. Bacteria secrete the exoenzyme lipase, which hydrolyzes sebum triglycerides to glycerol, and free fatty acids, which exhibit comedogenic properties [12, 20].

Given the important role of microorganisms in the etiopathogenesis of the disease, the main means of treating patients with mild acne and moderate disease are antimicrobial agents for topical use. In 2016, new guidelines for the treatment of acne patients were issued in Europe, America and Canada. For the treatment of acne requires an individual approach to the patient, taking into account the form and severity of the disease. Recommended methods must include topical therapy, antibiotics [1, 5, 15, 19]. Most commonly used dosage forms in which the main active ingredients are erythromycin, clindamycin, benzoyl peroxide, azelaic acid or combinations thereof. Sometimes used extemporaneously made forms according to ancient recipes using salicylic acid and chloramphenicol. In severe forms of the disease include systemic antibiotic therapy. Most often, the tetracycline antibiotic doxycycline is used for this purpose $[6,10,17]$.

The effectiveness of such treatment regimens cannot be considered high, because the treatment is long-term and the appearance of patients' skin remains unattractive after treatment. At the current level of resistance of microorganisms to antibiotics, the low effectiveness of traditional acne treatment regimens may be due to this phenomenon. Data on the current state of susceptibility of microorganisms involved in the development of acne to antimicrobials are insufficient to make suggestions for the correction of treatment regimens. The sensitivity of acne pathogens to antiseptics from among the quaternary ammonium compounds, natural derivatives of bromothyrosine, remains unexplored. It is worth studying the prospects of using the antagonistic effect of probiotic strains of lactobacilli in the complex treatment of this disease.

The aim of the study was to study the sensitivity of microorganisms involved in the development of acne to antimicrobials and the antagonistic effect of probiotic strains of lactobacilli.

\section{Materials and methods}

The content of rash elements of 60 patients with papulopustular acne of moderate severity was studied by bacteriological method. The test material was plated on blood meat-peptone agar (MPA). GasPak EZ gas generating packages were used to create anaerobic conditions.

Identification of isolated microorganisms was performed taking into account morphological, tinctorial, cultural and biochemical properties. Biochemical properties of isolated staphylococcal strains were determined using test systems STAFItest 16 .

The sensitivity of the isolated strains of microorganisms to oxacillin, cefazolin, ceftriaxone, chloramphenicol, doxycycline, cyprfloxacin, clindamycin was determined using the standard disco-diffusion method (DDM). Minimum bactericidal (MBC) concentrations of antibiotics most commonly used in the treatment of acne, antiseptic decamethoxine (1.10-decamethylene-bis- $n, \quad n$ dimethylmen-tihoxycarbonylmethyl, ammonium dichloride) and 2-[(1S, 6R)3,5-Dibromo-1,6-dihydroxy-4methoxycyclohexa-2,4-dien-1-yl] acetonitrile (Aeroplysinin 1) was determined by serial dilutions of antibiotics in a liquid nutrient medium [14].

The sensitivity of isolated strains of staphylococci and propionate bacteria to the antagonistic effect of culture of Lactobacillus acidophilus isolated from a serial sample of the drug Linex-forte (Sandos, Slovenia) was determined. Isolation of pure culture of lactobacilli was performed using a selective medium MRS-agar.

Determination of the level of antagonistic activity was performed by the method of two-layer agar. To do this, the suspension of the studied culture of lactobacilli in sterile isotonic sodium chloride solution based on the final concentration of 108 colony-forming units per $1 \mathrm{ml}$ of nutrient medium (CFU/ml) was added to the molten meatpeptone agar and poured into Petri dishes. After cooling the agar, a second layer $(10 \mathrm{ml})$ of molten agar was poured on its surface. In the lower layer, sown with lactobacilli, created optimal conditions for the cultivation of microaerophilic lactobacilli, eliminating the need to use anaerobic techniques. The plates were incubated for two hours at $37^{\circ} \mathrm{C}$.

Subsequently, a pure culture of bacteria isolated from acne patients (staphylococci or propiobacteria) was quantified on Gold cups prepared in this way. At the end of the daily incubation, the number of colonies grown on the 
agar surface was counted. As a control, cups prepared in a similar manner, in the lower layer of the nutrient medium of which probiotic strains of microorganisms were not made. The antagonistic activity of the studied strains of lactobacilli was evaluated by the degree of reduction in the number of CFU of bacteria compared to the control.

\section{Results}

Gram-positive coccal microorganisms were isolated from 40 subjects $(80.0 \%)$ who tested positive. Of the isolated cocci, $87.5 \%$ (35 strains) belonged to the species S. epidermidis. In one case, $S$. aureus was isolated, in two more - $S$. hominis, two strains of isolated coccal bacteria were assigned to the genus Kocuria. Propionibacterum acnes cultures were isolated in 15 patients $(30.0 \%)$. In particular, in $10.0 \%$ of cases propiobacteria were sown in monoculture, and in other cases - in association with staphylococci. In 10 patients $(16.7 \%)$ from the material taken for bacteriological examination of microorganisms could not be isolated.

The level of sensitivity of the isolated strains of microorganisms to antibiotics, determined by the discodiffusion method, is shown in Figure 1.

The data in Figure 1 show that the selected strains of bacteria showed low sensitivity to antibiotics, which are most often used in the topical therapy of acne patients in the form of soft or liquid dosage forms (clindamycin, erythromycin and chloramphenicol). At the same time propionobacteria show higher sensitivity, in comparison with staphylococci. Thus, about half of the isolated strains of propionobacteria were sensitive to erythromycin. Of the isolated strains of cocci, only $17.5 \%$ were sensitive to this antibiotic. A relatively high level of sensitivity of isolated strains of propionate bacteria to chloramphenicol $(80.0 \%)$ was found, while in the coccal microflora this indicator was much lower $(32.5 \%)$. Only about half of the isolated strains of both types of bacteria were sensitive to clindamycin.

In severe forms of acne, doxycycline is used

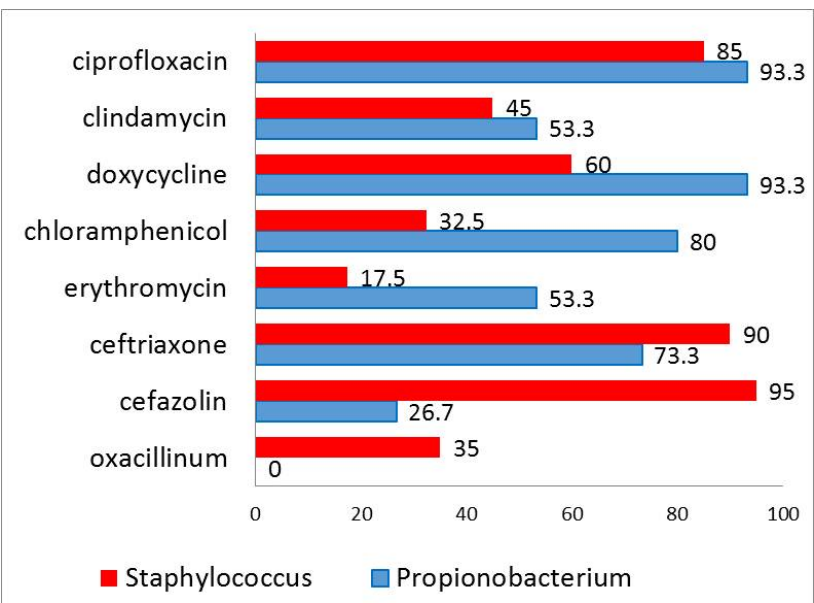

Fig.1. Sensitivity of isolated bacterial strains to antibiotics (\% of susceptible strains).
Table 1. Sensitivity characteristics of selected strains of Staphylococcus spp. and Propionibacterium spp. to antibiotics and antiseptics.

\begin{tabular}{|c|c|c|}
\hline \multirow{3}{*}{$\begin{array}{l}\text { Antimicrobial } \\
\text { drug }\end{array}$} & \multicolumn{2}{|c|}{ Genus of microorganisms } \\
\hline & $\begin{array}{c}\text { Staphylococcus } \\
(n=40)\end{array}$ & $\begin{array}{l}\text { Propionibacterium } \\
\qquad(\mathrm{n}=15)\end{array}$ \\
\hline & \multicolumn{2}{|c|}{ Minimum bactericidal concentration $(\mathrm{M} \pm \mathrm{m}, \mu \mathrm{g} / \mathrm{ml})$} \\
\hline Erythromycin & $620.8 \pm 134.7$ & $7.234 \pm 2.512$ \\
\hline Clindamycin & $504.7 \pm 122.5$ & $39.28 \pm 9.61$ \\
\hline Benzoyl peroxide & $92.12 \pm 14.57$ & $392.2 \pm 49.4$ \\
\hline Salicylic acid & $>1250$ & $416.3 \pm 22.7$ \\
\hline Aeroplysinin 1 & $24.53 \pm 3.21$ & $12.45 \pm 1.72$ \\
\hline Decamethoxine & $2.928 \pm 0.718$ & $1.475 \pm 0.431$ \\
\hline
\end{tabular}

systemically. According to our data, propionates have a high level of sensitivity to it (93.3\%). However, staphylococci, which support the inflammatory response in the lesions, are characterized by a much lower rate $(60.0 \%)$ of sensitivity to this antibiotic.

High levels of sensitivity of isolated strains of staphylococci were detected in relation to cephalosporins of I and III generations (95.0\% and $90.0 \%$, respectively). However, these antibiotics are used only systemically. The high level of sensitivity of the isolated strains of both types of bacteria to ciprofloxacin allows to predict the appropriate therapeutic efficacy in acne topical application of this drug, however, dosage forms based on it for the treatment of acne have not been developed to date.

The results of quantitative determination of the level of sensitivity of isolated strains of staphylococci and propionate bacteria to erythromycin, clindamycin, antiseptics benzoyl peroxide, salicylic acid, decamethoxine and the natural derivative of bromothyrosine Aeroplysinin 1 are summarized in Table 1.

The mean MBC values of erythromycin and clindamycin for staphylococci shown in Table 1 are not an objective reflection of the level of susceptibility of this genus, as for susceptible strains MBC ranged from 4-32 $\mu \mathrm{g} / \mathrm{ml}$. However, such strains were a significant minority. Stable strains of staphylococci remained viable in the presence of $4000 \mu \mathrm{g} / \mathrm{ml}$ antibiotics.

Against the background of the above average, a significantly higher level of vulnerability of propionate bacteria to the studied antibiotics is obvious, compared to staphylococci. After all, the MBC of ethithromycin and clindamycin for propionibacterium is $7.234 \mu \mathrm{g} / \mathrm{ml}$ and $39.28 \mu \mathrm{g} / \mathrm{ml}$, respectively.

In contrast, an antiseptic with a peroxide mechanism of bactericidal action of benzoyl peroxide was more active against selected strains of staphylococci $(M B C=92.12 \mu \mathrm{g} / \mathrm{ml})$. However, the isolated strains of propionate bacteria were less sensitive to this drug (MBC=392.2 $\mu \mathrm{g} / \mathrm{ml})$.

Salicylic acid is part of anti-acne drugs, taking into account, mainly, its keratolytic effect. However, it is believed that this compound has an antiseptic effect. Listed in Table 1 average 
Table 2. Quantitative characteristics of the growth inhibition of acne pathogens in the presence of lactobacilli.

\begin{tabular}{|c|c|c|}
\hline \multirow{3}{*}{ Culture of microorganisms } & \multicolumn{2}{|c|}{ Cultivation conditions } \\
\hline & $\begin{array}{l}\text { ordinary } \\
\text { (control) }\end{array}$ & $\begin{array}{c}\text { in the presence of } \\
\text { Lactobacillus acidophilus }\end{array}$ \\
\hline & \multicolumn{2}{|c|}{ quantitative characteristics $(\mathrm{CFU} / \mathrm{ml}, \mathrm{M} \pm \mathrm{m})$} \\
\hline Propionibacterium acnes & $10^{8} \pm 1.5 \times 10^{3}$ & $10^{2} \pm 18.7$ \\
\hline Staphylococcus spp. & $10^{8} \pm 2.3 \times 10^{3}$ & $10^{5} \pm 3.7 \times 10^{2}$ \\
\hline
\end{tabular}

MBC of salicylic acid for acne pathogens indicates a slight antimicrobial effect. Thus, staphylococci were insensitive to salicylic acid at the maximum concentration studied (1250 $\mu \mathrm{g} / \mathrm{ml}$ ). Propionate bacteria died in the presence of at least $400 \mu \mathrm{g} / \mathrm{ml}$ of this drug.

Aeroplysinin 1 was the first natural bromothyrosine isolated from the sponge Aplysina aerophoba. Since then, its antiviral, antibacterial, anti-inflammatory, antiangiogenic, action has been detected $[4,7,8]$. Due to a wide range of biological action, Aeroplysinin 1 is called a multitarget (multipurpose) biologically active compound, aspects of medical use of which require detailed research [8]. The antimicrobial activity of this compound against pathogens of acne remained unexplored. We determined that Propionibacterium acnes and Staphylococcus spp. show a fairly high level of sensitivity to Aeroplysinin 1, the MBC of which for them is $12.45 \pm 1.72 \mu \mathrm{g} / \mathrm{ml}$ and $24.53 \pm 3.21 \mu \mathrm{g} / \mathrm{ml}$, respectively.

Domestic antiseptic decamethoxine belongs to the quaternary ammonium compounds. The drug has a high level of antimicrobial activity, so it is widely used in purulent surgery, pulmonology, gynecology, ophthalmology and others. In terms of antimicrobial activity, decamethoxine has significant advantages over antibiotics and other domestic and foreign antiseptics of the same chemical series (benzalkonium chloride, cetylpyridinium chloride, miramistin). Thus, according to various authors, the MBC of decamethoxine for Staphylococcus aureus ranges from $1.5 \mu \mathrm{g} / \mathrm{ml}$ to $3.5 \mu \mathrm{g} / \mathrm{ml}$, and for epidermal staphylococci is even lower [18, 22].

We determined that the average MBC of decamethoxine for isolated strains of staphylococci involved in the acne development was $2.928 \pm 0.718 \mu \mathrm{g} / \mathrm{ml}$. All isolated strains of propionate bacteria also showed a high level of sensitivity to decamethoxine $(\mathrm{MBC}=1.475 \pm 0.431 \mu \mathrm{g} / \mathrm{ml})$. These results suggest that decamethoxine may be an effective component of complex means of topical acne therapy.

Recent studies have shown that probiotic strains of lactobacilli are able to inhibit the biological activity of staphylococci isolated from the purulent elements of acne vulgaris [13]. We studied the sensitivity of isolated strains of staphylococci and propionates to the antagonistic effect of culture of Lactobacillus acidophilus, isolated from a serial sample of the drug Linex Forte (Sandos, Slovenia). Evaluation of antagonistic activity was performed on the growth rate of the tested strain of opportunistic bacteria on a normal nutrient medium and in the presence of lactobacilli in a two-layer medium. The results are illustrated in Table 2.

The results shown in table 2 indicate a high level of sensitivity of bacteria of etiological importance in the development of acne to the antagonistic effect of the probiotic strain of lactobacilli.

The number of colony-forming units of staphylococci on bilayer plates inoculated with lactobacilli was approximately 103 times less than in the control. The population of Propionibacterium acnes decreased in the presence of lactobacilli by 106 times. Obviously, it is worth exploring the possibility of using probiotic drugs in the acne complex treatment.

\section{Discussion}

Summarizing the above, it should be noted that the results of our bacteriological studies of the content of acne rash elements confirm the etiological role of Propionibacterium acnes and Staphylococcus spp. in the development of this disease. General threatening trends in the spread of the phenomenon of resistance of microorganisms to antimicrobials extend to the pathogens of acne. The level of resistance of bacteria involved in the acne development to the most commonly used in the acne treatment antimicrobials is quite high and can have a negative impact on the effectiveness of treatment of patients. Less than half of the isolated strains of staphylococci were sensitive to erythromycin, chloramphenicol, clindamycin. It is known that the activity of this type of bacteria contributes to the chronicity of pathological changes in the skin and the development of complicated forms of acne.

Of the two members of the microbial association involved in the acne development, propionate bacteria are more sensitive to the effects of antimicrobial drugs. However, draw attention to the opposites in the sensitivity of associates to different drugs: if strains of Propionibacterium acnes show high sensitivity to erythromycin, clindamycin and low sensitivity to benzoyl peroxide, staphylococci, by contrast, are resistant to these antibiotics and relatively sensitive. In the real existence of the microbial association in the lesion, such a phenomenon can increase the ability of microorganisms to survive and in the process of antimicrobial therapy to reduce its effectiveness. As a result, among the acne treatment, the advantage should obviously belong to the dosage forms of the combined multicomponent composition.

Given the long duration of the period when topical acne therapy is mainly drugs from the above list, and microorganisms accelerate the spread of mechanisms of resistance to antimicrobials, there is a need to study the effectiveness and implementation of new highly effective antimicrobials. The results of the study of the sensitivity of acne pathogens to the antimicrobial drugs decamethoxine and Aeroplysinin 1 in vitro indicate the prospects of creating 
on their basis means of topical acne therapy. A high level of sensitivity of Propionibacterium acnes and Staphylococcus spp. to the antagonistic effect of Lactobacillus acidophilus opens the possibility of topical use of probiotics in the treatment of acne vulgaris.

\section{Conclusions}

1. Strains of Propionibacterium acnes and Staphylococcus spp., which are currently involved in the development of acne, are characterized by a high level of resistance to erythromycin, clindamycin, chloramphenicol, benzoyl peroxide and other antimicrobials, which are

\section{References}

[1] Araviyskaya, E. R., \& Sokolovsky, E. V. (2013). Системная антибиотикотерапия акне: некоторые дискуссионные вопросы [Systemic antibiotic therapy for acne: some controversial issues]. Вестник дерматологии и венерологии - Vestnik dermatologii i venereologii, 6 (90), 117-121.

[2] Bagmet, A. N., \& Shapovalova, O. V. (2003). Коррекция нарушений микробиоценоза кожи при легкой форме угревой болезни [Correction of skin microbiocenosis disorders in mild acne]. Дерматологія та венерологія - Dermatology and venereology, 1(8), 44-46.

[3] Bhate, K., \& Williams, H. C. (2013). Epidemiology of acne vulgaris. British Journal of Dermatoljgy, 3(168), 474-485. doi: 10.1111/ bjd.12149

[4] Binnewerg, B., Schubert, M., Voronkina, A., Muzychka, L., Wysokowski, M., Petrenko, I., \& Ehrlich, H. (2020). Marine biomaterials: Biomimetic and pharmacological potential of cultivated Aplysina aerophoba marine demosponge. Material Science and Engineering: C, (109), 110566. Access mode: doi :10.1016/j.msec.2019.110566

[5] Butareva, M. M., Znamenskaya, L. F., Kappusheva, I. A., Spiridonova, E. V., \& Egorova, Yu. Yu. (2011). Принципы комбинированной терапии акне [Principles of combination therapy for acne]. Вестник дерматологии и венерологии - Vestnik dermatologii i venereologii, 6(87), 3-17.

[6] Del Rosso, J. Q., Thiboutot, D., Gallo, R., Webster G., Tanghetti, E., Eichenfield, L. F., ... \& Zaenglein A. (2013). Consensus recommendations from the American Acne \& Rosacea Society on the management of rosacea, part 2: a status report on topical agents. Cutis, 92, 277-284. PMID: 24416742

[7] Fattorusso, E., \& Minale, L. S. G. (1972). Aeroplysinin-1, an antibacterial bromo-compound from the sponge Verongia aerophoba. Jornal of Chemical Society, (1), 16-18. doi: 10.1039/p19720000016

[8] Garcia-Vilas, J. A., Martinez-Poveda, B., Quesada, A. R., \& Medina, M. A. (2015). Aeroplysinin-1, a Sponge-Derived MultiTargeted Bioactive Marine Drug. Marine Drugs, 14(1), 1. doi: 10.3390/md14010001

[9] Gollnick, H. P. (2015). From new findings in acne pathogenesis to new approaches in treatment. Journal of the European Academy of Dermatology and Venereology,5(29), 1-7. doi: $10.1111 / j d v .13186$

[10] Hoover, W. D., Davis, S. A., Fleischer, A. B., \& Feldman, S. R. (2014). Topical antibiotic monotherapy prescribing practices in acne vulgaris. Journal of Dermatological Treatment, 2(25), 97-99. doi: 10.3109/09546634.2013.852297

[11] Kalyuzhna, L. D., \& Petrenko, A. V. (2014). Тяжкі форми акне: можливості лікування [Severe forms of acne: treatment options]. Український медичний часопис - Ukrainian currently used in the main list of anti-acne drugs as active substances.

2. The antimicrobial component of acne treatment regimens needs to be replenished with modern antimicrobials, to which propionibacterium and staphylococci remain highly sensitive.

3. It should be considered promising to upgrade the arsenal of topical acne therapy with drugs based on the quaternary ammonium compound decamethoxine, a derivative of bromothyrosine Aeroplysinin 1 and probiotic drugs containing lactobacilli strains with high antagonistic activity.

Medical Journal, 6(104), 1-3.

[12] Kutasevich, Ya. F., Mashtakova, I. A., Bagmet, A. N., \& Shapovalova, O. V. (2003). Микробиоценоз кожи у больных угревой болезнью и пути его коррекции [Skin microbiocenosis in patients with acne and ways of its correction]. Дерматологія та венерологія - Dermatology and venereology, 1(8), 43-47.

[13] Lavryk, G. S, \& Korniychuk, O. P. (2020). Антимікробна активність лактобацил відносно стафілококів, виділених 3 біоплівок хворих acne vulgaris [Antimicrobial activity of lactobacilli against staphylococci isolated from biofilms of patients with acne vulgaris]. Мікробіологія і біотехнологія - Microbiology and biotechnology, 1(48), 69-79. doi: 10.18524/ 2307-4663.2020.1(48).200905

[14] Methodical instructions MB 9.9.5-143-2007 (2007). Визначення чутливості мікроорганізмів до антибактеріальних препараmis [Determination of sensitivity of microorganisms to antibacterial drugs]. Київ - Kyiv.

[15] Monakhov, S. A. (2016). Рациональная терапия акне [Rational therapy of acne]. Український журнал дерматології, венерології, косметології - Ukrainian Journal of Dermatology, Venereology, Cosmetology, 4(63), 70-78.

[16] Murillo N., \& Raoult, D. (2013). Skin microbiota: overview and role in the skin diseases acne vulgaris and rosacea. Futur Microbiology, 2(8), 209-222. doi: 10.2217/fmb.12.141

[17] Naumova, L. O, \& Sulik, Ya. O. (2016). Диференційована терапія вугрової хвороби у жінок молодого і зрілого віку з урахуванням гормональних порушень [Differentiated therapy of acne in young and mature women, taking into account hormonal disorders]. Український журнал дерматології, венерології, косметології - Ukrainian Journal of Dermatology, Venereology, Cosmetology, 11(60), 17-25.

[18] Paliy, G. K, Pavlyuk, S. V, Dudar, A. A, Paliy, D. V, \& Kulyk, A. V. (2018). Характеристика резистентності мікроорганізмів до антимікробних препаратів [Characteristics of resistance of microorganisms to antimicrobial drugs]. Вісник Вінницького національного медичного університету - Reports of Vinnytsia National Medical University, 3(22), 417-421. doi: 10.31393/reports-vnmedical-2018-22(3)-04

[19] Savoskina, V. O. (2019). Акне. Новые возможности лечения (в соответствии с европейскими и американскими руководствами 2016 г. по лечению акне) [Acne. New treatment options (in line with the 2016 European and American guidelines for acne treatment)]. Український журнал дерматології, венерології, косметології - Ukrainian Journal of Dermatology, Venereology, Cosmetology, 4(75), 55-64. doi: 10.30978/UJDVK2019-4-55

[20] Svirid-Dzyadykevych, O. S. (2016). Вугрова хвороба: су- 
часні погляди на патогенез і лікування та визначення перспективних напрямів підвищення ефективності терапії [Acne: modern views on the pathogenesis and treatment and identification of promising areas for improving the effectiveness of therapy]. Український журнал дерматології, венерології, косметології - Ukrainian Journal of Dermatology, Venereology, Cosmetology, 4(63), 41-49.

[21] Yaakubi Randa. (2017). Особливості мікробного пейзажу шкіри у хворих на вугрову хворобу [Peculiarities of microbial skin landscape in patients with acne]. Дерматологія ma венерологія - Dermatology and venerology, 1(75), 30-33.

[22] Yurchyshyn, О. І. (2016) Вивчення протимікробної дії антисептиків відносно стафілококів - збудників піодермій з різними механізмами MLS-резистентності [Study of the antimicrobial effect of antiseptics on Staphylococci - causes of pyodermia with different mechanisms of MLS-resistance]. Буковинський медичний вісник - Bukovinian Medical Herald, 3(79), 197-201. 